Artikel Penelitian

\title{
Profil Bakteri Asam Laktat dan Evaluasi Sensori dari Tempe Bungkus Daun Jati yang Disuplementasi dengan Daun Kelor
} Lactic Acid Bacteria Profile and Sensory Evaluation of Teak Leaf-Wrapped Tempeh Supplemented with Moringa Leaves

Stella Magdalena ${ }^{*}$, Yogiara ${ }^{2}$, Adi Yulandi ${ }^{3}$

1 Program Studi Teknologi Pangan, Fakultas Teknobiologi, Universitas Katolik Indonesia Atma Jaya, Jakarta

2Program Studi Magister Bioteknologi, Fakultas Teknobiologi, Universitas Katolik Indonesia Atma Jaya, Jakarta

3Program Studi Biologi, Fakultas Teknobiologi, Universitas Katolik Indonesia Atma Jaya, Jakarta

*Korespondensi dengan penulis (stella.magdalena@atmajaya.ac.id)

Artikel ini dikirim pada tanggal 4 Maret 2020 dan dinyatakan diterima tanggal 27 Februari 2021. Artikel ini juga dipublikasi secara online melalui https://ejournal2.undip.ac.id/index.php/jatp. Hak cipta dilindungi undang-undang. Dilarang diperbanyak untuk tujuan komersial.

Diproduksi oleh Indonesian Food Technologists® @ $@ 2021$

\section{Abstrak}

Tempe bungkus daun jati merupakan produk pangan fermentasi tradisional Indonesia yang kaya protein, serat, dan vitamin yang sangat popular di Kabupaten Blora, Jawa Tengah. Penelitian ini bertujuan mengetahui pengaruh penambahan daun kelor pada tahapan perendaman dan peragian dalam proses produksi tempe terhadap profil bakteri asam laktat (BAL) dan tingkat kesukaan. Daun kelor segar dan serbuk disuplementasikan dengan variasi konsentrasi pada proses produksi tempe kacang kedelai. Hasil penelitian menunjukkan bahwa daun kelor tidak menghambat aktivitas pertumbuhan dari kapang Rhizopus. Penambahan serbuk daun kelor sebanyak $1 \mathrm{x}$ dan $2 \mathrm{x}$ (b/b) dari total jumlah ragi pada proses peragian menghasilkan tekstur tempe yang kompak. Semakin tinggi konsentrasi air perasan daun kelor dalam proses perendaman, jumlah total bakteri asam laktat menurun hingga $10^{3}$ $\mathrm{CFU} / \mathrm{g}$. Profil BAL dari tempe bungkus daun jati dengan ataupun tanpa suplementasi daun jati mengandung BAL dari genus Weissella. Tempe bungkus daun jati dengan suplementasi $1 \mathrm{x}(\mathrm{b} / \mathrm{b})$ serbuk daun kelor sangat berpotensi untuk disosialisasikan sebagai pangan fungsional kepada masyarakat.

Kata kunci: tempe bungkus daun jati, daun kelor, bakteri asam laktat, sensori, probiotik

\section{Abstract}

Tempeh wrapped in teak leaves is a traditional Indonesian fermented food product that is rich in protein, fiber, and vitamins which is very popular in Kabupaten Blora, Central Java. This study aimed to investigate the effect of Moringa leaves addition in the soaking and fermentation stages of tempeh production towards the profile of lactic acid bacteria ( $L A B)$ and the level of respondent acceptance. Fresh and powdered leaf was supplemented in various doses to soybean tempeh production. As results, Moringa leaves did not inhibit the growth of Rhizopus. The addition of Moringa leaf powder as much as $1 x$ and $2 x(w / w)$ of the total amount of yeast in the fermentation process produced a compact tempeh texture. The higher the concentration of Moringa leaf juice in the soaking process reduced total number of lactic acid bacteria to $10^{3} \mathrm{CFU} / \mathrm{g}$. LAB profile of teak leaf-wrapped tempeh with or without teak leaf powder supplementation contained $L A B$ that belongs to the genus Weissella. Teak leaf-wrapped tempeh supplemented by $1 x(w / w)$ Moringa leaf powder has a potential value to be socialized as functional food to the community.

Keywords: teak leaf-wrapped tempeh, Moringa leaves, lactic acid bacteria, sensory, probiotic

\section{Pendahuluan}

Tempe merupakan sumber protein nabati yang umum dikonsumsi di Indonesia dan diketahui memiliki nilai fungsional terhadap kesehatan, diantaranya mencegah terjadinya diare, sumber antioksidan, dan mereduksi munculnya penyakit kardiovaskular serta kanker (Astuti et al., 2001; Nout and Kiers, 2005). Konsumsi tempe juga dapat meningkatkan fungsi kognitif otak pada komunitas lansia (Hogervorst et al., 2008; Hogervorst et al., 2011). Tempe juga dapat meningkatkan komposisi bakteri yang bermanfaat di dalam usus manusia (Stephanie et al., 2018). Menurut Badan Pusat Statistik, rata-rata konsumsi tempe per kapita seminggu di Indonesia pada tahun 2007-2017 sebanyak $138 \mathrm{~g}$. Pengalaman dan metode yang diwariskan secara turun temurun pada proses pembuatan tempe di tiap daerah biasanya mengikuti ketersediaan sumber daya alam yang ada. Salah satu daerah penghasil tempe terbesar di provinsi Jawa Tengah yaitu Kabupaten Blora.

Kabupaten Blora memiliki hutan jati terluas di Jawa Tengah (Ulyatin dan Ba'in, 2020). Selain potensi kayu, masyarakat memanfaatkan daun tanaman jati sebagai media pembungkus dalam produksi tempe. Rata-rata industri rumah tangga di Jawa Tengah menghabiskan $70 \%$ dari ketersediaan kacang kedelai untuk menjadi tempe, termasuk tempe bungkus daun jati, dengan aroma dan cita rasa khas yang siap dipasarkan (Arnanda et al., 2015).

Tipe fermentasi yang terbuka pada produksi tempe memungkinkan komunitas mikroba yang bersifat aerob obligat ataupun anaerob fakultatif dari lingkungan bersama Rhizopus spp. sebagai ragi, menghidrolisis senyawa-senyawa kompleks kacang kedelai menjadi senyawa sederhana yang lebih mudah dicerna dan meningkatkan nilai nutrisinya (Liem et al., 1977; Nout 
and Kiers, 2005; Barus et al., 2008). Aktivitas mikroba selama proses fermentasi berperan dalam transformasi bahan pangan sehingga dapat meningkatkan kandungan nutrisi dan cita rasa (Bigot et al., 2016). Keberadaan bakteri asam laktat pada komunitas mikroba tersebut menjadikan tempe sebagai salah satu sumber probiotik yang mampu meningkatkan respon imun (Soka et al., 2015).

Selain tanaman jati, kabupaten Blora memiliki potensi sumber daya alam lainnya yang sangat bermanfaat yaitu tanaman kelor (Moringa oleifera) yang sangat bermanfaat dalam mengatasi permasalahan gizi buruk di Indonesia (Akbar et al., 2019). Daun kelor memiliki kandungan nutrisi dan manfaat bagi kesehatan sebagaimana penelitian Moyo et al. (2011), daun kelor kering memiliki kandungan 19 asam amino, asam lemak, vitamin $E, \beta$-karoten, dan mineral yang jauh lebih tinggi dibandingkan daun kelor segar. Daun kelor merupakan sumber vitamin C, kalsium, protein, senyawa fenolik, dan flavonoid (Razis et al., 2014). Ekstrak daun kelor, diantaranya memiliki aktivitas antiinflamasi (Razis et al. 2014), antioksidan (Fitriana et al., 2018) dan anti-kanker (Razis et al., 2014). Oleh karena itu, suplementasi daun kelor pada tempe diduga dapat meningkatkan kualitas dan manfaat tempe.

Pemanfaatan daun kelor sebagai suplementasi pada produk probiotik yoghurt telah diteliti oleh peneliti terdahulu. Ilona dan Ismawati (2015) melaporkan pengaruh penambahan ekstrak daun kelor berpengaruh nyata terhadap warna, aroma, kekentalan dan rasa, namun tidak berpengaruh nyata terhadap tekstur dan kesukaan dengan jumlah BAL sebesar 1,2 x 104 CFU/ml. Hal ini juga sejalan dengan penelitian sebelumnya (Kuikman and O'Connor, 2015) yang menyatakan bahwa penambahan daun kelor pada produk yoghurt yang mengandung pisang tidak menurunkan nilai kualitas sensori dibandingkan dengan probiotik yoghurt kontrol. Sampai saat ini masih sedikit informasi mengenai penggunaan daun kelor pada pembuatan tempe, sehingga penelitian ini menjadi salah satu kegiatan penelitian yang penting untuk dilakukan.

Tujuan dari penelitian ini adalah memproduksi tempe yang dibugkus daun jati dengan suplementasi daun kelor. Penambahan dilakukan dengan dua perlakuan yaitu serbuk daun kelor ditambahkan bersamaan dengan pemberian ragi dan air perasan daun kelor segar digunakan pada perendaman kacang kedelai. Selanjutnya tempe modifikasi tersebut dikarakterisasi dari profil bakteri asam laktat dan tingkat kesukaan. Penelitian ini sangat bermanfaat untuk mendapatkan informasi tentang potensi penggunaan daun kelor dalam menghasilkan tempe.

\section{Materi dan Metode \\ Materi}

Bahan yang digunakan meliputi kacang kedelai putih dan ragi komersial RaprimaTM. Daun kelor segar diperoleh dari tanaman kelor di daerah Jakarta Barat dan serbuk daun kelor komersial Kelorina ${ }^{\mathrm{TM}}$ merupakan produk dari Kabupaten Blora. Daun Jati diperoleh dari hutan milik Kampus BSD, Universitas Katolik Indonesia
Atma Jaya. Total dan profil bakteri asam laktat dianalisis dengan media de Man Rogosa Sharpe Agar (Oxoid, Inggris) disuplementasi dengan $\mathrm{CaCO}_{3}$ dan Solg Genomic DNA Prep Kit (SolGent, Korea Selatan). Alat yang digunakan meliputi inkubator (Memmert $\mathrm{GmbH}$, Jerman), elektroforesis (Bio-Rad Laboratories Inc., Amerika Serikat), mesin thermocycler ProFlex PCR System (ThermoFisher Scientific, Amerika Serikat), Vilber Gel Doc System (Vilber Lourmat, Perancis).

\section{Metode}

Penelitian ini dilakukan pada bulan MeiSeptember 2019 di Laboratorium Mikrobiologi Pangan dan Teknologi DNA, Fakultas Teknobiologi, Universitas Katolik Indonesia Atma Jaya, Jakarta. Eksperimen ini menggunakan 2 macam perlakuan yaitu penambahan serbuk daun kelor pada tahapan peragian dan penambahan air perasan daun kelor segar pada proses perendaman kacang kedelai.

\section{Produksi Tempe}

Proses pembuatan tempe dilakukan dengan metode yang diadaptasi dari para pengrajin tempe di Kabupaten Blora, yang sejalan dengan metode Winarno dan Reddy (1986). Kacang kedelai dicuci untuk menghilangkan kotoran, yang kemudian direbus selama 20 menit, dan dilepaskan kulit arinya. Kacang kedelai yang sudah dipisahkan kulit arinya, direndam dengan menggunakan air bebas klorin selama semalam lalu direbus kembali selama 20 menit, ditiriskan, dan dikeringudarakan. Ragi tempe sebanyak $2 \%$ (b/b) ditambahkan pada kacang kedelai dan diaduk secara merata. Pada tahap ini, kacang kedelai siap untuk dibungkus dengan daun jati. Modifikasi perlakuan penambahan serbuk daun kelor dan penggunaan air perasan daun kelor segar dilakukan pada tahap ini.

\section{Modifikasi Pembuatan Tempe}

Serbuk daun kelor ditambahkan pada saat peragian dengan variasi konsentrasi yaitu $1 \mathrm{x}, 2 \mathrm{x}$, dan $5 \mathrm{x}$ (b/b) dari total jumlah ragi yang diberikan. Konsentrasi suplementasi terbaik dipilih berdasarkan dari tekstur tempe yang dihasilkan.

Daun kelor segar dipetik dan dipisahkan dari ranting. Daun kelor diperas dan variasi konsentrasi tertentu digunakan sebagai air rendaman kacang kedelai. Air perasan untuk perendaman dibuat dengan cara menimbang sebanyak $100 \mathrm{~g}$ daun kelor segar, dimasukkan ke dalam $100 \mathrm{ml}$ air, dan diperas selama 10 menit (Diantoro et al., 2015). Variasi konsentrasi air rendaman yang digunakan yaitu $100 \%$ air perasan dan $100 \%$ air dengan perbandingan 1:1 (v/v).

\section{Penghitungan Jumlah Bakteri Asam Laktat (BAL)}

Sebanyak $1 \mathrm{~g}$ tempe dimasukkan dalam $9 \mathrm{ml}$ garam fisiologis $0,85 \%(\mathrm{~b} / \mathrm{v})$. Dilusi bertingkat dibuat dan sebanyak $100 \mu \mathrm{L}$ suspensi disebar pada media de Man Ragosa Sharpe agar (MRSA) yang disuplementasi dengan $\mathrm{CaCO}_{3}$ (Abubakr and Al-Adiwih, 2017). Media diinkubasi selama 48 jam pada suhu $35{ }^{\circ} \mathrm{C}$ secara anaerob. Pertumbuhan BAL pada media diobservasi 
dengan terbentukya zona bening di sekitar koloni dan dihitung jumlahnya. Tempe bungkus daun jati tanpa perlakuan digunakan sebagai kontrol. Sebanyak 5 isolat BAL dari tempe tanpa perlakuan dan 5 isolat BAL dari tempe dengan penambahan serbuk daun kelor dimurnikan pada media MRSA untuk dianalisis profilnya secara molekuler.

\section{Uji Evaluasi Sensori}

Evaluasi sensori dilakukan pada 30 orang panelis tidak terlatih dengan variasi gender dan usia. Uji ini dilakukan pada tempe bungkus daun jati tanpa perendaman air perasan daun kelor dengan variasi perlakuan pada penambahan serbuk daun kelor yang meliputi tanpa perlakuan (sebagai kontrol), 1x (b/b) serbuk, dan $2 x(b / b)$ serbuk. Setiap sampel tempe diberikan kode tertentu. Uji kesukaan dilakukan dengan metode scoring menggunakan skala 1 (sangat tidak disukai) - 5 (sangat disukai). Setiap sampel tempe dipotong dengan ukuran $2 \times 2 \times 2 \mathrm{~cm}^{3}$ dan digoreng hingga berwarna kecoklatan. Panelis diberi 3 sampel, 1 gelas air mineral, dan borang penilaian di atas nampan. Setiap panelis diminta minum air putih di antara mencicip tiap sampel untuk menetralisasi indera pengecap. Penilaian meliputi aroma, tekstur, rasa, aftertaste, dan keseluruhan penampakan. Setiap data dikumpulkan dan dianalisis untuk diukur rerata. Grafik spider web nilai rata - rata penilaian dari panelis dibuat menggunakan package 'fmsb' pada aplikasi R (https://www.rproject.org)

\section{Analisis Profil Bakteri Asam Laktat}

Sebanyak total 6 isolat yang diperoleh dari tempe bungkus daun jati dengan suplementasi $1 \mathrm{x}(\mathrm{b} / \mathrm{b})$ serbuk daun kelor dipilih untuk diidentifikasi secara molekuler. Sebagai pembanding, lima isolat yang diisolasi dari tempe bungkus daun jati asal Kabupaten Blora juga diidentifikasi. Analisis profil BAL dilakukan melalui sekuensing gen penyandi 16S rRNA. DNA diisolasi dengan menggunakan Solg Genomic DNA Prep Kit (SolGent, Daejeon, Korea Selatan) mengacu pada protokol standar dari produsen. Gen penyandi 16S rRNA diamplifikasi dengan menggunakan primer universal $7 \mathrm{~F}$ (5'-AGAGTTTGAT(C/T)(A/C)TGGCTCAG-3') dan 7R (5'-CACCGCTACACATGGAG -3') (Lane et al., 1991). Komposisi campuran reaksi PCR terdiri dari $1 \mu$ l cetakan DNA, $1 \mu \mathrm{l}$ forward primer (7F), $1 \mu \mathrm{l}$ reverse primer (7R), $25 \mu \mathrm{l}$ GoTaq Green Master Mix, dan $22 \mu \mathrm{l}$ of $\mathrm{ddH}_{2} \mathrm{O}$ dengan volume total $50 \mu \mathrm{L}$. Amplifikasi gen dikondisikan sebagai berikut: pre-denaturasi pada suhu $94^{\circ} \mathrm{C}$ selama 5 menit, denaturasi pada suhu $94^{\circ} \mathrm{C}$ selama 30 detik, penempelan pada suhu $57{ }^{\circ} \mathrm{C}$ selama 30 detik, perpanjangan pada suhu $72{ }^{\circ} \mathrm{C}$ selama 60 detik, dan pasca perpanjangan pada suhu $72^{\circ} \mathrm{C}$ selama 5 menit.

Produk hasil amplifikasi dipisahkan pada gel elektroforesis dengan 1\% agarosa selama 60 menit pada 90V dan divisualisasi dengan menggunakan Vilber Gel Doc System (Vilber Lourmat, Perancis). Produk PCR disekuensing oleh First Base Laboratories Sdn Bhd, Malaysia. Hasil sekuens diedit menggunakan program SeqTrace versi 0.8.1 dan dibandingkan dengan database genbank (www.ncbi.nlm.nih.gov) menggunakan algoritma BLASTN (Altschul et al., 1990). Pohon filogenetika dikonstruksi menggunakan program MEGA X (Kumar et al., 2018), dengan metode NeighborJoining dan model Jukes-Cantor dengan replikasi bootstrapping sebanyak 1000.

\section{Hasil dan Pembahasan}

Produksi Tempe dengan Suplementasi Daun Kelor

Pembuatan tempe bungkus daun jati dengan suplementasi daun kelor tidak menghambat pertumbuhan kapang Rhizopus (Gambar 1a). Hal ini bertolak belakang dengan penelitian Manenji et al. (2017), ekstrak daun kelor dengan air suling pada konsentrasi $30 \%$ mampu menghambat pertumbuhan Rhizopus stolonifer yang diisolasi dari buah tomat yang matang. Aktivitas penghambatan pertumbuhan terhadap kapang Rhizopus sp. juga ditunjukkan dari ekstrak biji daun kelor dengan menggunakan pelarut kloroform (Manenji et al., 2017).

Karakteristik tempe yang disuplementasi dengan serbuk daun kelor masih memenuhi standar SNI 3144:2015 yaitu memiliki penampakan yang berwarna permukaan putih dan tidak menghasilkan aroma amoniak. Namun, kriteria tempe yang bertekstur kompak tidak terpenuhi pada suplementasi serbuk daun kelor sebesar 5x (b/b) (Gambar 1b). Miselium kapang Rhizopus tetap mampu menjalin butiran kacang kedelai, tetapi serbuk daun kelor rontok ketika tempe dipotong, maka penambahan serbuk daun kelor yang digunakan pada tahapan selanjutnya yaitu tempe bungkus daun jati dengan suplementasi serbuk daun kelor $1 x$ dan $2 x(b / b)$. Penampakan morfologi tempe dengan perlakuan perendaman pada semua variasi konsentrasi tidak berbeda jika dibandingkan dengan tempe tanpa perlakuan dan memenuhi standar SNI 3144:2015.

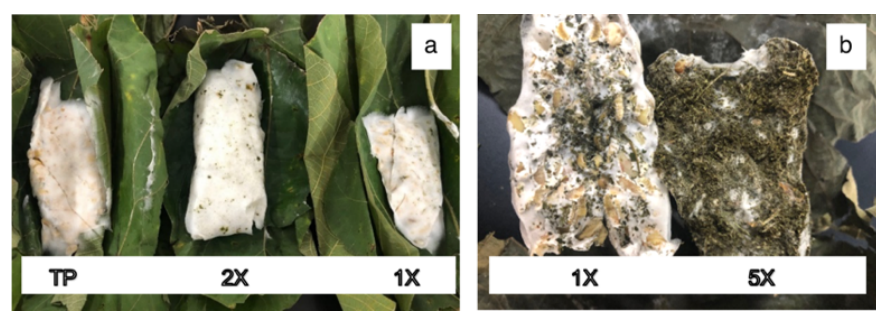

Gambar 1 Tampilan luar (a) dan tampilan dalam (b) dari tempe bungkus daun jati. TP: tanpa perlakuan sebagai kontrol; $1 \mathrm{x}, 2 \mathrm{x}$, $5 x$ : penambahan serbuk daun kelor dengan kelipatan terhadap jumlah massa ragi

\section{Jumlah Bakteri Asam Laktat}

Bakteri asam laktat yang ditumbuhkan pada media MRS dan $\mathrm{CaCO}_{3}$ ditandai dengan pembentukan zona bening di sekeliling koloni karena asam organik yang dihasilkan (khususnya asam laktat) dapat bereaksi dengan kalsium karbonat. Berdasarkan Tabel 1, perendaman dengan air perasan daun kelor berpengaruh pada penurunan jumlah isolat BAL. Semakin tinggi tingkat konsentrasi air perasan daun kelor, jumlah isolat BAL semakin menurun hingga menjadi $10^{5} \mathrm{CFU} / \mathrm{g}$. Hal ini menunjukkan bahwa air perasan daun kelor segar memiliki aktivitas antibakteri. 
Tabel 1. Total BAL pada tempe dengan penambahan air perasan dan serbuk daun kelor

\begin{tabular}{lll}
\hline $\begin{array}{ll}\text { Porsi air perasan } \\
\text { daun kelor }\end{array}$ & $\begin{array}{l}\text { Rasio serbuk daun } \\
\text { kelor terhadap ragi }\end{array}$ & Total BAL (CFU/g)
\end{tabular}
$(\mathrm{b} / \mathrm{b})$

\begin{tabular}{lcc}
\hline Air perasan 0\% & $0($ TP $)$ & $1,14 \times 10^{8}$ \\
\cline { 2 - 3 } & $1 \mathrm{x}$ & $9,10 \times 10^{7}$ \\
\cline { 2 - 3 } & $2 \mathrm{x}$ & $6,50 \times 10^{7}$ \\
\hline Air tanah 50\%: air & $1 \mathrm{x}$ & $2,90 \times 10^{6}$ \\
\cline { 2 - 3 } perasan 50\% & $2 \mathrm{x}$ & $1,24 \times 10^{7}$ \\
\hline Air perasan 100\% & $1 \mathrm{x}$ & $1,00 \times 10^{5}$ \\
\cline { 2 - 3 } & $2 \mathrm{x}$ & $4,00 \times 10^{5}$ \\
\hline
\end{tabular}

Keterangan: TP berarti tanpa perlakuan

Daun kelor diketahui memiliki sifat antimikroba dan antiinflamasi (Yulianto, 2020). Menurut Abalaka et al. (2012), daun kelor yang diekstrak menggunakan air destilata dan dikonsentratkan memiliki aktivitas antibakteri terhadap Escherichia coli dan Salmonella thypi. Daun kelor yang diekstrak dengan menggunakan pelarut kloroform, zona ihibisi yang terbentuk dapat lebih tinggi. Hal ini dapat terjadi karena hasil ekstrak dengan kloroform memiliki kandungan metabolit sekunder yang meliputi alkaloid, flavonoid, saponin, dan tannin. Ekstrak etanol dari daun kelor diketahui memiliki kandungan komponen bioaktif, seperti alkaloid, tannin, dan fenol yang mempengaruhi terhadap aktivitas penghambatan E. coli dan Salmonella (Imohiosen et al., 2014). Hal ini juga sejalan dengan penelitian Oluduro (2012), ekstrak air dan methanol pada daun kelor memiliki aktivitas terhadap bakteri entopatogenik.

Lain halnya dengan penelitian Villarruel-López et al. (2018), jumlah BAL yang diisolasi dari feses mencit diabetes yang mengkonsumsi daun kelor kering tidak terdapat perbedaan enumerasi dengan mencit diabetes kontrol dan mencit non-diabetes. Namun, aktivitas antibakteri terhadap BAL dalam penelitian tersebut diperoleh dari daun kelor yang telah dikeringkan.

Air perasan daun kelor dalam produksi pangan fermentasi yoghurt tidak berimbas pada pertumbuhan bakteri asam laktat sebagai starter yang digunakan (llona dan Ismawati, 2015). Penelitian tersebut memberikan hasil yang bertolak belakang dengan penelitian ini yang menunjukkan adanya sifat antibakteri air perasan daun kelor terhadap BAL yang ditandai dengan penurunan jumlah BAL pada tempe yang direndam pada air perasan daun kelor segar (Tabel 1).

Ditinjau dari total jumlah BAL, pada tempe tanpa penambahan air rendaman daun kelor memenuhi standar yang menyatakan bahwa produk pangan fungsional harus memiliki probiotik berkisar 106-108 CFU/ml (Martins et al., 2013; Tripathi and Giri, 2014; Scourboutakus et al., 2017). Namun, untuk produk tempe dengan penambahan $100 \%$ air perasan daun kelor tidak lagi memenuhi syarat pangan fungsional.

Secara umum, penambahan serbuk daun kelor pada konsentrasi $1 \mathrm{x}$ dan $2 \mathrm{x}(\mathrm{b} / \mathrm{b})$ pada semua perendaman tidak mempengaruhi jumlah total isolat $\mathrm{BAL}$ (Tabel 1). Pada penelitian El-Sayed et al. (2016) dan Dixit et al. (2018) menunjukkan bahwa penambahan serbuk daun kelor dalam pembuatan produk minuman fermentasi berpotensi meningkatkan nilai fungsional dari minuman tersebut bahkan dalam menghambat pertumbuhan total bakteri, kapang, dan khamir;-bahkan mampu meningkatkan jumlah bakteri probiotik yang memiliki pengaruh positif terhadap kesehatan manusia.

\section{Evaluasi Sensori}

Uji ini dilakukan pada tempe bungkus daun jati tanpa perendaman air perasan daun kelor dengan variasi perlakuan penambahan serbuk daun kelor yang meliputi tanpa perlakuan (sebagai kontrol), 1x (b/b) serbuk, dan 2x (b/b) serbuk (Gambar 2). Warna tidak menjadi salah satu parameter dalam penilaian evaluasi hedonik karena tempe diolah dengan cara digoreng sehingga dapat mempengaruhi hasil penilaian.

Tingkat kesukaan pada setiap variasi tempe dapat dilihat pada Gambar 3. Tempe tanpa perlakuan menunjukkan nilai sensori yang paling tinggi pada semua parameter dibandingkan tempe dengan suplementasi serbuk daun kelor. Grafik ini menunjukkan bahwa penilaian panelis terhadap parameter tekstur tempe cenderung tidak berbeda $(\approx 4)$. Parameter after taste dari tempe tanpa perlakuan $(4,35)$ sebagai kontrol masih lebih disukai oleh panelis dibanding sampel tempe lain. Semakin tinggi konsentrasi suplementasi serbuk daun kelor maka semakin rendah nilai sensori pada after taste. Yang dimaksud dengan after taste yang tidak disukai berdasarkan panelis yaitu adanya rasa yang tertinggal seperti green leaves flavour dan sedikit pahit.

Penilaian panelis terhadap dua tempe modifikasi dengan variasi konsentrasi suplementasi daun kelor menunjukkan perbedaan yang mencolok pada rasa $(1 \mathrm{x}=$ $3,8$ dan $2 x=3,45)$, sedangkan pada penilaian secara keseluruhan tidak terlalu berbeda $(1 x=3,8$ dan $2 x=3,6)$. Hasil ini serupa dengan penelitian Chizoba (2014) dan Bourekoua (2018) yang menunjukkan semakin tinggi penambahan konsentrasi serbuk daun kelor pada produk makanan, maka semakin rendah tingkat kesukaan oleh panelis. Hal ini dimungkinkan karena adanya aroma daun pada produk pangan, rasa pahit yang muncul, dan kandungan klorofil pada serbuk daun tersebut. Hasil evaluasi sensori mengindikasikan bahwa tempe dengan suplementasi serbuk daun kelor $1 \mathrm{x}(\mathrm{b} / \mathrm{b})$ berpotensi untuk dikembangkan sebagai suplemen pada produksi tempe bungkus daun jati untuk menghasilkan pangan fungsional yang dapat dikomersialkan.
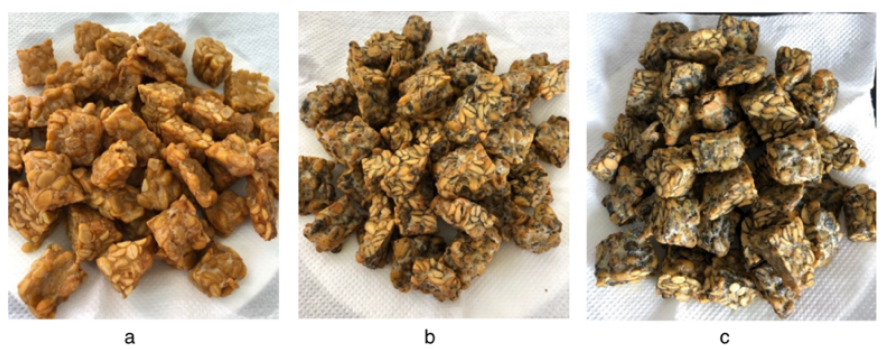

Gambar 2. Tampilan tempe bungkus daun jati tanpa perendaman air perasan daun kelor yang sudah digoreng dengan variasi konsentrasi serbuk daun kelor yang telah digoreng. Tampak pada gambar a, b, dan c adalah masingmasing tempe tanpa perlakuan dan dengan perlakuan serbuk daun kelor sebanyak $1 x$ dan $2 x$ dari total jumlah ragi. 


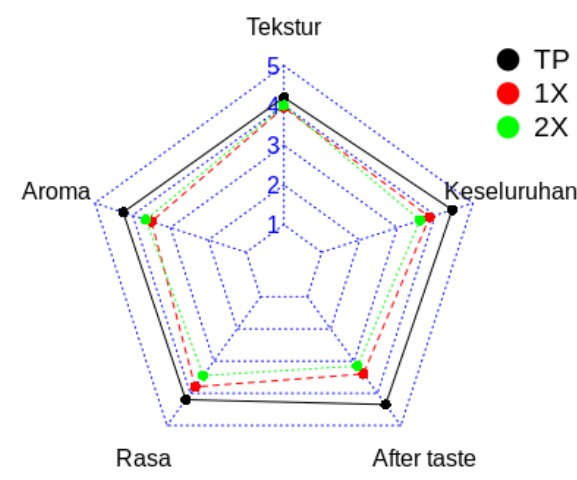

Gambar 3. Grafik spider web rata-rata penilaian panelis terhadap lima mutu sensori pada produk tempe bungkus daun jati. TP, $1 \mathrm{x}$, dan $2 \mathrm{x}$ adalah masing-masing tempe tanpa perlakuan dan dengan perlakuan serbuk daun kelor sebanyak $1 \mathrm{x}$ dan $2 \mathrm{x}$ dari total jumlah ragi.

Sejauh ini, modifikasi produk tempe banyak dilakukan pada variasi bahan baku ataupun produk variasi olahan tempe sebagai produk pangan siap saji. Seperti pada penelitian Ambari et al. (2014), tempe dijadikan sebagai bahan baku pembuatan sosis analog yang disuplementasi dengan jamur tiram memiliki tingkat penerimaan lebih dari $50 \%$. Tempe dengan bahan baku dari biji lotus mempengaruhi perubahan warna, tekstur, aroma dengan tingkat penerimaan terbaik pada substitusi maksimum 50\% dari biji lotus (Sarti et al., 2019). Penelitian ataupun publikasi yang menganalisis tingkat penerimaan pada produk tempe dengan suplementasi bahan alami tertentu relatif masih jarang. Namun, pembuatan tempe dengan suplementasi rempah-rempah ataupun rumput laut telah didaftarkan dalam paten dengan nomor P00201602869, S00201702800, dan P00199801334.

\section{Analisis Profil Bakteri Asam Laktat}

Berdasarkan hasil sekuensing, sebelas isolat terpilih dari tempe bungkus daun jati dengan penambahan serbuk $1 \mathrm{x}(\mathrm{b} / \mathrm{b})$ dan tempe bungkus daun jati asal Kabupaten Blora teridentifikasi mirip dengan genus Weissella dan Streptococcus (Tabel 2). Analisis filogenetika isolat BAL menunjukkan pengelompokan yang jelas berdasarkan genus bakteri (Gambar 4).

Isolat yang diidentifikasi molekuler dipilih secara acak sehingga tidak dapat menggambarkan keragaman keseluruhan bakteri probiotik BAL yang terdapat pada setiap sampel tempe. Namun, adanya variasi genus pada sampel tempe daun jati asal Kabupaten Blora tanpa penambahan serbuk daun kelor menunjukkan bahwa variasi ini dapat disebabkan oleh sumber daun jati yang berbeda ataupun karena adanya aktivitas antibakteri dari serbuk daun kelor. Analisis metagenomika pada tempe lain menunjukkan bahwa genus Lactobacillus sebagai genus dominan dan berkorelasi dengan perbedaan metode produksi terutama pada proses perendaman tempe (Radita et al., 2017).

Identifikasi secara molekuler menggunakan marka gen 16S rRNA menunjukkan adanya dua klaster besar yaitu klaster Weissella dan Streptococcus. Perbandingan menggunakan database genbank terdapat tiga species genus Weissella dan satu species Streptococcus. Klaster Weissella terdapat pada tempe tanpa perlakuan dan tempe dengan suplementasi serbuk daun kelor. Genus Weissella merupakan salah satu golongan probiotik yang banyak ditemukan pada pangan fermentasi tradisional (Fusco et al., 2015). Weissella cibaria JW15 berhasil diisolasi dari Kimchi, pangan fermentasi tradisional asal Korea dan diketahui memiliki aktivitas antibakteri dan memenuhi sebagai kandidat probiotik (ketahanan terhadap asam, garam empedu, dan suhu tinggi) (Lee et al., 2013). Pangan fermentasi tradisional dari India, Idli batter, diketahui mengandung Weissella confusa yang mampu tumbuh dan bertahan terhadap kondisi pencernaan, memiliki aktivitas antioksidan, dan tidak memiliki aktivitas hemolisis sehingga memenuhi kriteria sebagai probiotik (Sharma et al., 2018).

Tabel 2 Identifikasi isolat BAL secara molekuler dari tempe bungkus daun jati

\begin{tabular}{lccc}
\hline $\begin{array}{l}\text { Jenis } \\
\text { Perlakuan }\end{array}$ & $\begin{array}{l}\text { Nama } \\
\text { isolat }\end{array}$ & Kemiripan & $\begin{array}{l}\text { Tingkat } \\
\text { kemiri- } \\
\text { pan (\%) }\end{array}$ \\
\hline $\begin{array}{l}\text { Suplementa } \\
\text { si serbuk } \\
\text { daun kelor }\end{array}$ & $\mathrm{A}$ & Weissella confusa & 100 \\
\cline { 2 - 4 } $1 \mathrm{x}$ & $\mathrm{B}$ & Weissella confusa & 100 \\
\cline { 2 - 4 } & $\mathrm{C}$ & Weissella confusa & 100 \\
\cline { 2 - 4 } & $\mathrm{H}$ & Weissella cibaria & 100 \\
\cline { 2 - 4 } & $\mathrm{N}$ & Weissella confusa & 100 \\
\hline Tanpa & WBeissella confusa & 100 \\
\cline { 2 - 4 } $\begin{array}{l}\text { perlakuan } \\
\text { serbuk daun } \\
\text { kelor }\end{array}$ & $\mathrm{JBL}-15$ & Streptococcus gallolyticus & 99 \\
\cline { 2 - 4 } & $\mathrm{JBL}-16$ & Weissella paramesentroides & 100 \\
\cline { 2 - 4 } & $\mathrm{JBL}-17$ & Weissella paramesentroides & 100 \\
\cline { 2 - 4 } & $\mathrm{JBL}-20$ & Weissella paramesentroides & 100 \\
\hline
\end{tabular}

Hasil serupa juga diperoleh pada penelitian Rambitan et al. (2018), W. cibaria dan W. confusa berhasil diisolasi dari fermentasi kol merah (Brassica oleacera $\mathrm{L}$ ) dan juga berada pada cluster yang sama. $W$. paramesentroides diisolasi dari saluran pencernaan belut asal Indonesia (Anguilla bicolor McClelland) dan diketahui memiliki aktivitas antibakteri sehingga berpotensi sebagai probiotik pada bidang perikanan (Dinoto et al., 2018). Semua isolat genus Weissela terletak dalam 2 cluster dan menunjukkan kekerabatan yang berdekatan dibandingkan dengan genus Streptococcus (Gambar 4).

Streptococcus gallolyticus juga merupakan salah satu species yang biasa ditemukan pada pangan fermentasi tradisional Afrika berbasis susu (Jans et al., 2017). S. gallolyticus subsp. Macedonicus CRL 415 mampu memproduksi folat, bertahan pada kondisi lingkungan gastrointestinal, serta mampu melekat pada sel epitel usus sehingga menjadi kandidat kuat sebagai starter dan probiotik pada produk pangan (Laino et al., 2019). 


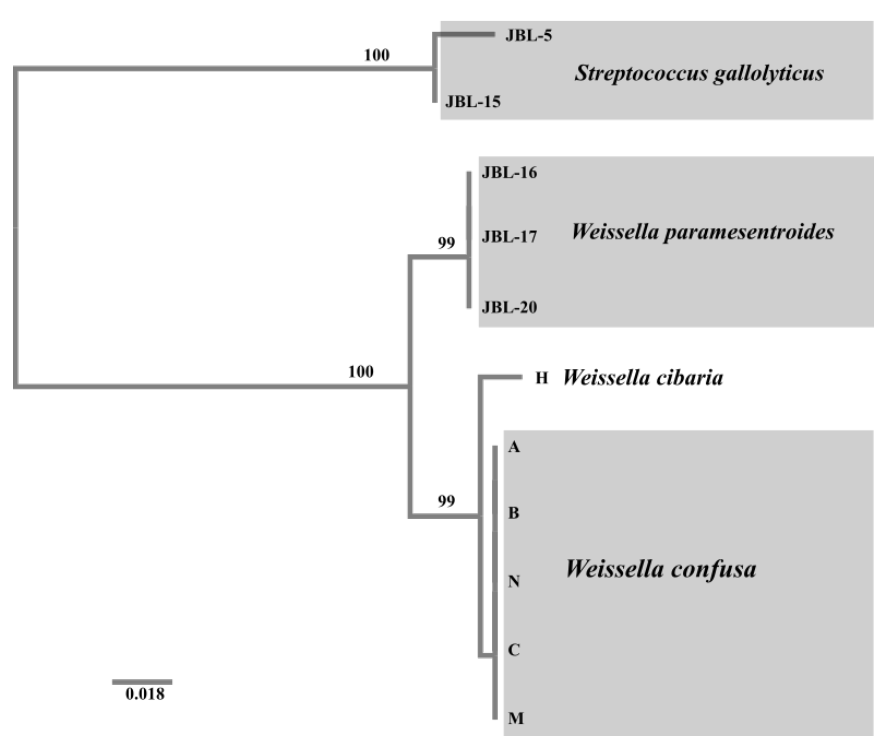

Gambar 4. Pohon filogenetik berdasarkan sequence basa nukleotida gen 16S rRNA dari isolat BAL tempe bungkus daun jati tanpa perlakuan (JBL-5, JBL-15, JBL-16, JBL-17, JBL-20) dan tempe bungkus daun jati dengan penambahan serbuk daun kelor ( $A, B, C, H, N, M)$. Pohon filogenetik disusun menggunakan metode Neighbor-Joining dan model Jukes-Cantor dengan replikasi bootstrapping sebanyak 1000 .

Untuk memperoleh informasi lebih lanjut terkait karakterisasi isolat BAL sebagai kandidat probiotik, isolat tersebut perlu diuji ketahanan pada kondisi saluran pencernaan, kemampuan hemolisis darah, kemampuan menghasilkan $\mathrm{Y}$-Aminobutyric Acid, uji resistensi terhadap antibiotik, dan kemampuan dalam menghasilkan senyawa antimikroba ataupun efek terhadap sistem imun. Produk tempe yang dihasilkan perlu diuji lebih lanjut untuk memastikan produk tersebut memiliki nilai kandungan nutrisi yang lebih tinggi dibandingkan tempe pada umumnya, ataupun apakah produk tempe memenuhi standar SNI.

\section{Kesimpulan}

Pembuatan tempe bungkus daun jati dengan suplementasi daun kelor tidak menghambat pertumbuhan Rhizopus dan dapat menghasilkan tempe yang sesuai dengan standar SNI, serta dapat diterima panelis. Profil BAL yang berhasil diperoleh, diketahui memiliki kemiripan dengan Weissella.

\section{Ucapan Terima Kasih}

Terima kasih kepada Pemerintah Kabupaten Blora yang telah mendanai penelitian ini melalui Program Riset Unggulan Daerah Nomor 077/016/2019.

\section{Daftar Pustaka}

Abalaka, M.E., Daniyan, S.Y., Oyeleke, S.B., Adeyemo, S.O. 2012. The antibacterial evaluation of Moringa oleifera leaf extracts on selected bacterial pathogens. Journal of Microbiology Research 2(2):1-4. DOI: 10.5923/j.microbiology. 20120202.01.
Abubakr M.A.S., Al-Adiwih, W.M. 2017. Isolation and identification of lactic acid bacteria from different fruits with proteolytic activity. International Journal of Microbiology and Biotechnology 2(2):58-64. DOI:10.11648/j.jimb.20170202.12.

Akbar, C.T., Suketi, K., Kartika, J.G. 2019. Panen dan pascapanen kelor (Moringa oleifera Lam.) organik di Kebun Organik Kelorina, Blora, Jawa Tengah. Buletin Agrohorti 7(3):247-254. DOI:10.29244/agrob.v7i3.30171.

Altschul, S.F., Gish, W., Miller, W., Myers, E.W., Lipman, D.J. 1990. Basic local alignment search tool. Journal of Molecular Biology 215:403-410. DOI:10.1016/S0022-2836(05)80360-2.

Ambari, D.P., Anwar, F., Damayanthi, E. 2014. Formulasi sosis analog sumber protein berbasis tempe dan jamur tiram sebagai pangan fungsional kaya serat pangan. Jurnal Gizi dan Pangan 9(1):65-72. DOI:10.25182/jgp.2014.9. $1 . \% 25 p$.

Arnanda, F., Kriswanto, Y., Izzatun, I., Nurlita, D., Fajriyani, A., Utami, T.W. 2015. Pemodelan ketahanan pangan kedelai (glysine soya max (Lenus\&Merril) di Provinsi Jawa Tengah dengan pendekatan spatial regression. Jurnal Statistika 3(1):13-19. DOI:10.26741/jsunimus.3.1.2015. $\% 25 p$.

Astuti, M., Meliala, A., Dalais, F.S., Wahlqvist, M.L. 2001. Tempe, a nutritious and healthy food from Indonesia. Asia Pacific Journal of Clinical Nutrition 9(4):322-325. DOI:10.1046/j.14406047.2000.00176.x.

Barus, T., Suwanto, A., Wahyudi, A.T., Wijaya, H. 2008. Role of bacteria in tempe bitter taste formastion: microbiological and molecular biological analysis based on 16S rRNA gene. Microbiology Indonesia 2(1):17-21. DOI:10.5454/mi.2.1.4.

Bigot, C., Meile, J., Remize, F., Strub, C. 2016. Fermented foods. Part I, Biochemistry and Biotechnology. 1'st edition, Montet D, Ray R-C, editor. CRC Press, Boca Raton, US. DOI:10.1201/b19872.

Bourekoua, H., Rozylo, R., Gawlik-Dziki, U., Benatallah, L., Zidoune, M.N., Dziki, D. 2018. Evaluation of physical, sensorial, and antioxidant properties of gluten-free bread enriched with Moringa oleifera leaf powder. European Food Research and Technology 244:189-195. DOI:10.1007/s00217017-2942-y.

Chizoba, N.N. 2014. Sensory evaluation of cookies produced from different blends of wheat and Moringa oleifera leaf flour. International Journal of Nutrition and Food Sciences 3(4):307-310. DOI:10.11648/j.ijnfs.20140304.21.

Diantoro, A., Rohman, M., Budiarti, R., Palupi, H.T. 2015. Pengaruh penambahan ekstrak daun kelor (Moringa oleifera L.) terhadap kualitas yoghurt. Jurnal Teknologi Pangan 6(2): 59-66. DOI:10.35891/tp.v6i2.469.

Dinoto, A., Sulistiani, S., Handayani, R., Julistiono, H. 2018. Weissella paramesentroides from intestine 
of Indonesian eel (Anguilla bicolor McClelland) and their potential antimicrobial property. AIP Conference Proceedings.

DOI: 10.1063/1.5062799.

Dixit, N.K.M., Hossain, S.K.A., Bharti, B.K., Singh, S.S., Mishra, S. 2018. Development of lassi using whey and moringa powder. International Journal of Current Microbiology and Applied Sciences 7(11):602-612. DOI:10.20546/ijcmas.2018. 711.073

El-Sayed, O.F., El-Taweel, H.S.M., El-Shibiny, A.A., Metwally, M.M.K. 2016. Using moringa leaves powder in production of probiotic yoghurt. SINAI Journal of Applied Sciences 5(2):197-208. DOI:10.21608/sinjas.2016.78645.

Fitriana, W.D., Ersam, T., Shimizu, K, Fatmawati, S. 2018. Antioxidant activity of Moringa oleifera extracts. Indonesian Journal of Chemistry 16(3):297-301. DOI:10.22146/ijc.21145.

Fusco, V., Quero, G.M., Cho, G-S., Kabisch, J., Meske, D., Neve, H., Bockelmann, W., Franz, C.M.A.P. 2015. The genus Weissella: taxonomy, ecology, and biotechnological potential. Frontiers in Microbiology 6:155. DOI:10.3389/fmicb.2015. 00155.

Hogervorst, E., Sadjimim, T., Yesufu, A., Kreager, P., Rahardjo, T.B. 2008. High tofu intake is associated with worse memory in elderly Indonesian men and women. Dementia Geriatric and Cognitive Disorders 26(1):50-7. DOI:10.1159/000141484.

Hogervorst, E., Mursjid, F., Priandini, D., Setyawan, H., Ismael, R.I., Stephan, B., Rahardjo, T.B. 2011. Borobudur revisited: Soy consumption may be associated with better recall in younger, but not in older, rural Indonesian elderly. Brain Research 1379:206-212. DOI:10.1016/j.brainres.2010.10. 083.

Ilona, A.D., Ismawati, R. 2015. Pengaruh penambahan ekstrak daun kelor (Moringa oleifera) dan waktu inkubasi terhadap sifat organoleptik yoghurt. Journal Tata Boga 4(3):151-159. DOI:10.35891/tp.v6i2.469.

Imohiosen, O., Gurama, H.H., Lamidi, T.B. 2014. Phytochemical and antimicrobial studies on Moringa oleifera leaves extracts. IOSR Journal of Environmental Science, Toxicology, and Food Technology 8(1):39-45. DOI:10.9790/240208143945.

Jans, C., Meile, L., Kaindi, D.W.M., Kogi-Makau, W., Lamuka, P., Renault, P., Kreikemeyer, B., Lacroix, C., Hattendorf, J., Zinsstag, J., Schelling, E., Fokou, G., Bonfoh, B. 2017. African fermented dairy products-overview of predominant technologically important microorganisms focusing on African Streptococcus infantairus variants and potential future applications for enhanced food safety and security. International Journal of Food Microbiology 250:27-36. DOI:10.1016/j.ijfoodmicro.2017.03.012.
Kuikman, M., O’Connor, C.P. 2015. Sensory evaluation of Moringa-probiotic yoghurt containing banana, sweet potato, or avocado. Journal of Food Research 4(5):165-171. DOI:10.5539/jfr. v4n5p165.

Kumar, S., Stecher, G., Li, M., Knyaz, C., Tamura, K. 2018. MEGA X: Molecular evolutionary genetics analysis across computing platforms. Molecular Biology and Evolution 35(6): 1547-1549. DOI:10.1093/molbev/msy096.

Lane, D.J. 1991. 16S/23S rRNA sequencing. In Nucleic acid techniques in bacterial systemic. Stackebrandt E, Goodfellow M, editor, p 115-175. John Wiley, Chichester.

Laiṅo, J.E., Levit, R., de LeBlanc, A.M., de Giori, G.S., LeBlanc, J.G. 2019. Characterization of folate production and probiotic potential of Streptococcus gallolyticus subsp. macedonicus CRL415. Food Microbiology 79:20-26. DOI:10.1016/j.fm.2018.10.015.

Lee, W.K., Ahn, S.B., Park, H.E., Lee, S.M., Kim, S.Y., Shon, M.Y. 2013. Characteristics and immunomodulatory effects of Weissella cibaria JW 15 isolated from kimchi, Korea traditional fermented food, for probiotic use. Journal of Biomedical Research 14(4): 206-211. DOI:10.12729/jbr.2013. 14.4.206.

Liem, I.T., Steinkraus, K.H., Cronk, T.C. 1977. Production of vitamin B-12 in tempeh, a fermented soybean food. Applied and Environmental Microbiology 34(6):773-776. DOI:10.1128/aem.34.6.773-776.1977.

Manenji, B.T., Mudyiwa, R.M., Midzi, J., Tsodzo, A. 2017. Antifungal effects of botanical leaf extracts of Lantana camara, Moringa oleifera, and Tagetes minuta on Rhizopus stolonifer in vitro. Journal of Agriculture and Ecology Research 11(2):1-8. DOI:10.9734/JAERI/2017/28371.

Martins, E.M.F., Ramos, A.M., Vanzela, E.S.L., Stringheta, P.C., Pinto, C.L.O., Martins, J.M. 2013. Products of vegetable origin: a new alternative for the consumption of probiotic bacteria. Food Research International 51(2013):764.770. DOI:10.1016/j.foodres.2013. 01.047.

Moyo, B., Masika, P.J., Hugo, A., Muchenje. 2011. Nutritional characterization of Moringa (Moringa oleifera Lam.) leaves. African Journal of Biotechnology 10 (60):12925-12933. DOI: 10.5897/AJB10.1599.

Nout, M.J.R., Kiers, J.L. 2005. Tempe fermentation, innovation and functionality: update info the third millennium. Journal of Applied Microbiology 98:789-805. DOI:10.1111/j.1365-2672.2004. 02471.x.

Oluduro, A.O. 2012. Evaluation of antimicrobial properties and nutritional potentials of Moringa oleifera Lam. Leaf in South-Western Nigeria. Malaysian Journal of Microbiology 8(2):59-67. DOI: $10.21161 / \mathrm{mjm} .02912$. 
Radita, R., Suwanto, A., Kurosawa, N., Wahyudi, A.T., Rusmana, I. 2017. Metagenome analysis of tempeh production: where did the bacterial community in tempeh come from? Malaysian Journal of Microbiology 13(4): 280-288. DOI:10.21161/mjm.101417.

Rambitan, G., Pelealu, J.J., Tallei, T.E. 2018. Isolasi dan identifikasi bakteri asam laktat hasil fermentasi kol merah (Brassica oleracea $\mathrm{L}$ ) sebagai probiotik potensial. Jurnal Bios Logos 8(2): 33-37. DOI:10.35799/jbl.8.2.2018.21447.

Razis, A.F.A., Ibrahim, M.D., Kntayya, S.B. 2014. Health benefits of Moringa oleifera. Asian Pacific Journal of Cancer Prevention 15(20):8571-8576. DOI:10.7314/APJCP.2014.15.20.8571.

Sarti, M.Y., Rhidowati, S., Lestari, S.D., Wulandari, R. 2019. Studi kesukaan panelis terhadap tempe dari biji lotus (Nelumbo nucifera) dan kedelai (Glycine max). Jurnal fishtech 8(2):34-41. DOI:10.36706/fishtech.v8i2.9665.

Scourboutakus, M.J., Franco-Arellano, B., Murphy, S.A., Norsen, S., Comelli, E.M. Abbè, M.R.L. 2017. Mismatch between probiotic benefits in trial versus food products. Nutrients 9(4):400. DOI:10.3390/nu9040400.

Sharma, S., Kandasamy, S., Kavitake, D., Shetty, P.H. 2018. Probiotic characterization and antioxidant properties of Weissella confusa KR780676, isolated from an Indian fermented food. LWTFood Science and Technology 97(2018):53-60. DOI:10.1016/j.Iwt.2018.06.033.

Soka, S., Suwanto, A., Sajuthi, D., Rusmana, I. 2015. Impact of tempeh supplementation on mucosal immunoglobulin A in Sprague-Dawley rats. Food Science and Biotechnology 24(4):1481-1486. DOI:10.1007/s10068-015-0191-z.
Stephanie, Kartawidjajaputra, F., Silo, W., Yogiara, Suwanto, A. 2018. Tempeh consumption enhanced beneficial bacteria in the human gut. Food Research 3(1):57-63. DOI:10.26656/fr. 2017.3(1).220.

Tripathi, M.K., Giri, S.K. 2014. Probotic functional foods: survival of probiotics during processing and storage. Journal of Functional Foods 9(2014):225-241. DOI:10.1016/j.jff.2014.04.030.

Ulyatin, N.C., Ba'in. Eksploitasi hutan jati di Kabupaten Blora tahun 1845-1949. Journal of Indonesian History 9(1):10-16. DOI:10.15294/jih.v9i1.40927

Villarruel-López, A., López-de la Mora, D.A., VázquezPaulino, O.D., Puebla-Mora, A.G., Torres-Vitela, M.R., Guerrero-Quiroz, L.A., Nuño, K. 2018. Effect of Moringa oleifera consumption on diabetic rats. BMC Complementary and Alternative Medicine 18:127. DOI:10.1186/ s12906-018-2180-2.

Winarno, F.G., Reddy, N.R. 1986. Tempe. Di dalam: Reddy NR, editor. Legume based fermented foods. CRC Press, Boca Raton, US. DOI:10.1201/9781351074001-13.

Yulianto, S. 2020. Identifikasi alkaloid pada daun kelor (Moringa oleifera L.). Jurnal Kebidanan dan Kesehatan Tradisional 5(1):55-57. DOI:10.37341/jkkt.v5i1.136. 